\title{
Town avenues as flight corridors for Long-eared Owls (Asio otus)
}

\section{Thomas Oliver MÉRÖ ${ }^{1,2 *} \&$ Antun ŽulJEviĆ ${ }^{2}$}

\author{
${ }^{\times}$Presented at $2^{\text {nd }}$ Hungarian Owl Research Conference held in Pécs on $11^{\text {th }}$ September 2020
}

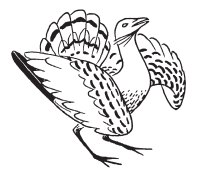

Received: September 07, 2020 - Revised: October 15, 2020 - Accepted: October 16, 2020

Mérö, Th. O. \& Žuljević, A. 2020. Town avenues as flight corridors for Long-eared Owls (Asio otus). - Ornis Hungarica 28(2): 19-23. DOI: 10.2478/orhu-2020-0014

\begin{abstract}
During winter, Long-eared Owls (Asio otus) usually roost in groups in urban areas, but their nocturnal movement patterns are less known. The aim of our study is to provide insight into the local-scale urban movement habits of Long-eared Owls. Our study was carried out between 2015 and 2019 in the autumn and winter period, by observations in the early evening and by ringing and recapture of owls in the town of Sombor (NE Serbia). We observed owls when leaving the roosting site located in the town centre following the greenery of the larger avenues towards the outskirts. Owls were sporadically observed in densely built areas of the town, narrow streets with less greenery. Ringing and recapture data suggest that owls were closely linked to the green corridors. They probably used these corridors for easier orientation and to prey on birds roosting in trees in the town, such as sparrows (Passer domesticus, P. montanus), Common Blackbirds (Turdus merula) or Fieldfares (T. pilaris) appearing in harsh winters, and sometimes also pigeons.
\end{abstract}

Keywords: green corridors, urban area, roosting site, Asio otus

Összefoglalás Az erdei fülesbagoly (Asio otus) télen csapatokba verődve, többnyire városi környezetben nappalozik, azonban éjszakai mozgásmintázata kevésbé ismert. Vizsgálatunk célja az volt, hogy betekintést nyerjünk a baglyok lokális léptékủ, városi mozgási szokásaiba. Kutatásunkat 2015 és 2019 között, az őszi és téli időszakban, föként a kora esti órákban végeztük megfigyeléssel, az egyedek gyürüzésével és visszafogásával Zombor városában (ÉNY Szerbia). Megfigyeltük, hogy a baglyok, miután elhagyták a nappalozó helyet, követték a fákban gazdag sugárutakat (zöld folyosók), melyek a város külterületeire vezetnek. Kevésbé használták viszont a sủrủn beépített területeket, melyeket szük utcák és gyér vegetáció jellemez. A gyürüzési és visszafogási adatok arra utalnak, hogy a baglyok szorosan kötődnek a zöld folyosókhoz. Feltételezhetö, hogy ezek a folyosók megkönnyítik a tájékozódásukat, és lehetőséget adnak a városban, fákon éjszakázó madarak - pl. verebek (Passer domesticus, P. montanus), fekete rigók (Turdus merula), vagy a zord teleken megjelenő fenyőrigók (T. pilaris), időnként galambok - zsákmányolására is.

Kulcsszavak: zöld folyosók, városi élőhely, nappalozó hely, erdei fülesbagoly

${ }^{1}$ Department of Tisza Research, Danube Research Institute, Centre for Ecological Research; 4026 Debrecen, Bem tér 18/c, Hungary

${ }^{2}$ Nature Protection and Study Society - NATURA, Milana Rakića 20, 25000 Sombor, Serbia

*corresponding author; e-mail: thomas.oliver.mero@gmail.com 


\section{Introduction}

Movement patterns of birds has been the subject of many studies (e.g. Mérő \& Žuljević 2014, Rechetelo et al. 2016). Birds may use natural or human made formations for orientation in their flight. Migrating birds take advance of valleys, canyons, meanders of rivers, forest-belts and/or tree rows that function as corridors taking them to their feeding, wintering or breeding ranges (e.g. Bentley \& Catterall 1997, Calm 1997). However, at a local scale, short bird movements (e.g. within urban habitat, forest) remain understudied and often unclear (Gillies \& St. Clair 2008). For example, some authors suggest that Sparrowhawks (Accipiter nisus) use the same foraging routes daily in the breeding period (Newton 1986). This might be related to the fact that birds of prey and owls may have hunting territories, even in the non-breeding period (Dawson \& Mannan 1991, Martinez et al. 1998). Ardia and Bildstein (1997) found that individuals of American Kestrel (Falco sparverius) were strongly linked to their hunting ranges in winter, occupying the same ranges during two or more consecutive winter seasons.

Long-eared Owls are nocturnal predatory birds that feed mostly on small mammals and sporadically on small- and medium-sized birds (Bertolino et al. 2001, Sándor \& Kiss 2008, Bozó et al. 2020). In the autumn and winter, Long-eared Owls roost, often in large numbers, in the canopies of deciduous and coniferous trees in urban or semi-urban areas in the nearest vicinity of humans (Makarova \& Sharikov 2015). They probably recognize that roosting sites in settlements have advantages such as higher temperatures and/or tend to be safer in winter than rural sites (Clergeau \& Simonnet 1996). In harsh winters with hard frosts and snowy periods, urban areas can provide additional feeding resources, such as roosting birds (Glue 1972). Unlike other owl species, Long-eared Owls have no territorial hunting ranges (Hume 1991), and therefore hunting traces are more difficult to explore. The aim of this study was to describe movement habits of Long-eared Owls between their roosting site and their supposed hunting sites.

\section{Material and methods}

The town of Sombor is located in north-western Serbia $\left(\mathrm{N} 45.79^{\circ}, \mathrm{E} 19.09^{\circ}\right)$. It is a typical lowland settlement ( $89 \mathrm{~m}$ a.s.1.) with a population of around 50,000 inhabitants. The climate is temperate continental with an average annual precipitation of ca. $590 \mathrm{~mm}$ and average annual temperature of $10.7^{\circ} \mathrm{C}$ (Tomić 1996). From the town centre, five main avenues run toward the outskirts containing at least two or more tree rows (Figure 1). Trees are planted along avenues (total length $121 \mathrm{~km}$, ca. 18,000 trees), in parks and in gardens of private houses (Vojnović 2001). The most frequent tree of the avenues is the common hackberry (Celtis occidentalis), some avenues are planted with London plane (Platanus $\times$ acerifolia), horse chestnut (Aesculus hippocastanum) and Japanese pagoda-tree (Sophora japonica). In gardens, usually coniferous trees, walnut (Juglans regia) and orchard trees occur. For more details, see Mérő and Žuljević (2010, 2014).

The fieldwork was conducted by observing and ringing of Long-eared Owls in the town during the autumn and winter from 2015 until 2019. Long-eared Owls roosted in the centre 


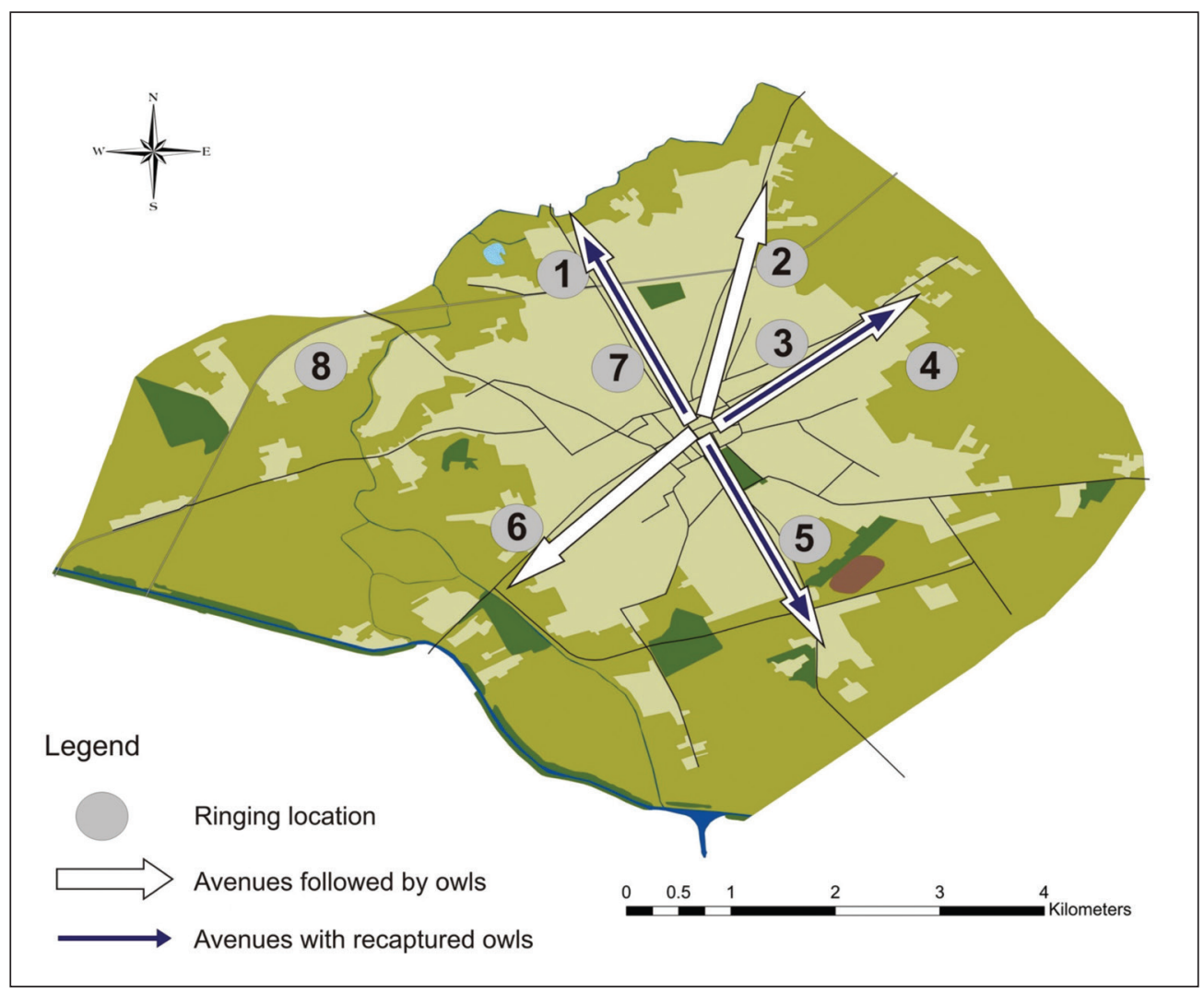

Figure 1. The schematic map of town Sombor. White arrows show the avenues followed by the Longeared Owls, while blue arrows represent the avenues with recaptures. Grey dots represent ringing locations

1. ábra Zombor város sematikus térképe. A fehér nyilak ábrázolják az erdei fülesbagoly által követett sugárutakat, a kék nyilak pedig a visszafogásokat. A szürke pöttyök a gyűrűzési helyszíneket jelölik

of the town near the courthouse (Figure 1). They often used deciduous trees for roosting, e.g. common hackberry trees, but later, during late autumn and winter, they occupied the surrounding coniferous trees. We have conducted observations of Long-eared Owls on the periphery of the town after sunset. Owls were captured by mist netting (mesh size $60 \times 60$ $\mathrm{mm}$ ) in the early evening hours from 16:30 until 21:30. We used several play-back sounds of field mice calls played from mobile device. The luring voice was mounted near to low, dense shrubs, or dense herbal vegetation, or near heaps of twigs. If the area was relatively open without shrubs, we surrounded the source of the sound by mist nets from two sides, i. e. mist nets were mounted V-shaped. In the case when the sampling location was grown by shrubs, we installed one or two nets (the first followed immediately by the second), the luring call was put in the middle below the nets. We marked owls with aluminium rings at eight locations in the town. We took basic biometric data and determined sex and age using the Euring codes (EURING 2010, Baker 2016). 


\section{Results and discussion}

We captured altogether 101 Long-eared Owls: 50 males, 49 females and two whose sex could not be determined. Thirty-nine were determined as young individuals (age category 3 or 5 , respectively), 53 as adults (age category 4 or 6 , respectively), and nine individuals could not be aged (Baker 2016). Besides Long-eared Owls, we ringed four Little Owls (Athene noctua) and two European Barn-owls (Tyto alba). Altogether seven individuals were recaptured, four were ringed as adults, and three as young birds. Three owls were recaptured during the same winter and four in the subsequent winter after ringing. All but one of the owls were recaptured in the same corridor they were ringed.

According to our observations, after leaving their roosting site, owls mainly follow the greenery of the main avenues that lead out of the town (Figure 1). We observed up to ten owls flying above the canopy of the trees in the avenues near the outskirts of the town. In the densely built parts of the town and in the outskirts with less greenery, we observed only one or two individuals. Our observations were supported by our ringing activities. Most owls were captured near green corridors.

Despite of the relatively few recaptures, there are implications that owls always use the same corridor (blue arrows in Figure 1), apart from one exception. The recapture of the owls is difficult at the location of ringing since they become more alert. We often observed individuals that did not even stop to listen for the mice call (despite we varied calls), suggesting that they already had the "bad" experience of being ringed. In March 2018, we had an opportunity to ring owls in a larger garden (location 7) in corridor 1 that is located halfway between ringing location 1 and the roosting site in the town centre (Figure 1). During three evenings, we have recaptured two owls that were ringed about two weeks earlier at location 1. Our observation contradicts the suggestion of Hume (1991) that Long-eared Owls do not have individual specific hunting territories. Our results suggest that fidelity towards each corridor may possibly be related to hunting areas in the rural areas outside the town.

The explanation for why owls follow the green avenues may be that birds use corridors for better orientation. The town avenues may lead them fast and directly to their possible hunting places in the outskirts and rural habitats. This may be related to the architectural concept of the town, i.e. all main avenues are radially positioned, leaving the centre towards the outskirts. Moreover, the dense canopy of the common hackberry trees and shrubs in the lower layer is an excellent roosting site for sparrows, thrushes and pigeons. Based on pellet analysis Laursen et al. (2004) reported that in the neighbouring villages of Sombor Long-eared Owls fed mostly on Common Vole (Microtus arvalis) and Apodemus mice. However, we assume that owls hunt on birds that roost in the green avenues. In the harsh and snowy winter of March 2018, we observed Long-eared Owls hunting Fieldfare (Turdus pilaris) roosting en masse in the canopy of the trees near corridor 1. Earlier, European Barn-owls were observed to hunt roosting House Sparrows (Passer domesticus) on London plane trees in Sombor (Mérő \& Žuljević 2010).

For stronger evidences and conclusions on the movements of Long-eared Owls between roosting sites and hunting areas further research is needed with larger number of marked individuals on two or more ringing sites per corridor, as well as radio tagging. 


\section{Acknowledgements}

The ringing permission was issued by the Centre for Animal Marking, Natural-history Museum in Belgrade and by the Ministry of Environmental Protection. The map was drawn by Katalin Varga. T.O.M was supported by the grant from the National Research, Development and Innovation Office of Hungary (NKFIH-OTKA PD 128002). The authors declare no competing interests.

\section{References}

Ardia, D. R. \& Bildstein, K. L. 1997. Sex-related differences in habitat selection in wintering American Kestrels, Falco sparverius. - Animal Behavior 53(6): 1305-1311. DOI: 10.1006/anbe.1996.0364

Baker, J. 2016. Identification of European Non-Passerines. - British Trust for Ornithology, Norfolk

Bentley, J. M. \& Catterall, C. P. 1997. The use of bushland, corridors, and linear remnants by birds in southeastern Queensland, Australia. - Conservation Biology 11(5): 1173-1189. DOI: $10.2307 / 2387400$

Bertolino, S., Ghiberti, E. \& Perrone, A. 2001. Feeding ecology of the Long-eared Owl (Asio otus) in northern Italy: is it a dietary specialist? - Canadian Journal of Zoology 79: 2192-2198. DOI: 10.1139/CJZ-79-12-2192

Bozó, L., Rutkai, T., Csathó, A. I. \& Bozóné Borbáth, E. 2020. Winter diet and roosting site fidelity of urban roosting Long-eared Owls (Asio otus), and the change in the species' population size in Southeast Hungary. - Ornis Hungarica 28(2): 1-18. DOI: 10.2478/orhu-2020-0013

Calm, J. B. 1997. Stream corridors for bird movement. - Wildlife Notes 2: 2-5.

Clergeau, P. \& Simonnet, E. 1996. Microclimate in communal roost sites of Starlings Sturnus vulgaris. - Journal of Ornithology 137: 358-361. DOI: 10.1007/BF01651076

Dawson, J. W. \& Mannan, W. R. 1991. The role of territoriality in the social organization of Harris Hawks. - The Auk 108: 661-672. DOI: 10.2307/4088106

EURING 2010. The EURING exchange-code 2000 Plus v112. - Thetford

Gillies, C. S. \& St. Clair, C. C. 2008. Riparian corridors enhance movement of a forest specialist bird in fragmented tropical forest. - Proceedings of the National Academy of Sciences of the USA 105: 19774-19779. DOI: 10.1073/pnas.0803530105

Glue, D. E. 1972. Bird prey taken by British owls. - Bird Study 19(2): 91-96. DOI: 10.1080/00063657209476330

Hume, R. 1991. Owls of the world. - Running Press, Philadelphia

Laursen, T. J., Fritze, E. \& Žuljević, A. 2004. Prey composition in the Long-eared Owl Asio otus winter diet at three localities in Bačka. - Ciconia 13: 194-196.

Martinez, D. R., Figueroa, R. A., Ocampo, C. L. \& Jaksic, F. 1998. Food habits and hunting ranges of Shorteared Owls (Asio flammeus) in agricultural landscapes of southern Chile. - Journal of Raptor Research 32(2): 111-115.

Makarova, T. \& Sharikov, A. 2015. Winter roost place selection of Long-eared Owls in European Russia. - Journal of Raptor Research 49(3): 333-336. DOI: 10.3356/JRR-13-65.1

Mérő, T. O. \& Žuljević, A. 2010. Birds of Sombor. - Nature Protection and Study Society - NATURA, Sombor

Mérö, T. O. \& Žuljević, A. 2014. Does the weather influence the autumn and winter movements of tits in urban areas? - Acta Zoologica Bulgarica 66(4): 505-510.

Newton, I. 1986. The Sparrowhawk. - T \& AD Poyser, Calton, Staffordshire

Rechetelo, J., Grice, A., Reside, A. E., Hardesty, B. D. \& Moloney, J. 2016. Movement Patterns, Home Range Size and Habitat Selection of an Endangered Resource Tracking Species, the Black-Throated Finch (Poephila cincta cincta). - PLoS ONE 11: e0167254. DOI: 10.1371/journal.pone.0167254

Sándor, A. D. \& Kiss, B. J. 2008. Birds in the diet of wintering Long-eared Owls (Asio otus) in the Danube Delta, Romania. - Journal of Raptor Research 42(4): 292-295. DOI: 10.3356/JRR-08-02.1

Tomić, P. 1996. Klima. - In: Đuričić, J. (ed.) Opština Sombor. - Prirodno-matematički fakultet, Institut za geografiju, Prosveta, Novi Sad, pp. 16-21. (in Serbian)

Vojnović, M. 2001. Sombor. - Publikum, Sombor 